\title{
Strain A of Sugarcane Mosaic Virus Isolated from Sour Grass in Ishigaki Island, Okinawa, Japan
}

\author{
Yoshihiro Oнтsu* and Tadayuki Gomi**
}

Key Words : sugarcane mosaic virus, sour grass, identification.

Sour grass (Paspalum conjugatum Berg.) is one of the wild gramineous plants widely distributed in Ishigaki Iisland. Mosaic-diseased plants of the species have been recorded in this island since $1967^{1}$. We observed a large number of sour grass plants (10-20\%) affected by the disease in a few locations of the island. As these plants appeared to present the same symptoms, we tried to isolate the causal virus from mosaic-diseased sour grass plants which were collected at Maesato, Ishigaki island in the spring of 1980. Mosaic-diseased sugarcane plants had not yet been observed in this island in the same year, although the disease had occurred in Okinawa Main Island since $1977^{2}$.

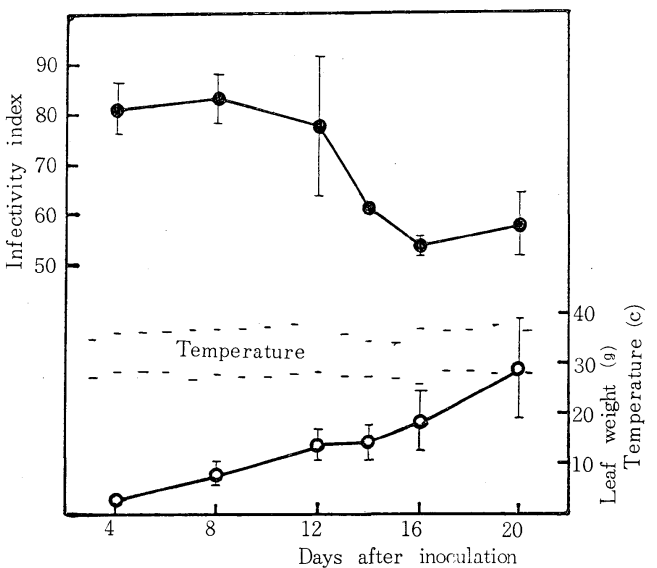

Fig. 1. Multiplication of the virus isolate in Zea mays under high temperature, 26-38 C (av. 32C).

: Infectivity index, $\bigcirc$ : Leaf weight

The present experiments were conducted in order to identify the causal virus of mosaic-diseased sour grass and to determine its relations with sugarcane mosaic disease. It was demonstrated that the isolate corresponds to the strain A of sugarcane mosaic virus (SCMV-A) ${ }^{3,4}$. Thus we report the results of our investigations, a part of which was already published in $1982^{5)}$.

The isolate was mechanically inoculated to corn plants cv. Nakadama, which were grown in a glass-house, and leaves showing mosaic symptoms were used for this experiment. Some of the leaves were freezedried for storage. Infected leaves were homogenized with potassium phosphate buffer

* Okinawa Branch of Tropical Agriculture Research Center, Ishigaki 907-01, Japan 農林水産省 熱帯農業研究センター沖縄支所

** Tohoku National Agricultural Experiment Station, Morioka 020-01, Japan＼cjkstart農林水産省東北農業 試験場

1) Nishizawa, T., Miyara, K., Tsudome, K. and Moromizato, A. (1967). Bull. Ryukyu Sug. Development Assoc. $11: 1-7$. 2) Yamauchi, S., Uehara, K., Tokashiki, I., Miyara, A., Shimozi, T., Miyara, K., Kinzyoh, T. and Hanashiro, S. (1978). Proc. Assoc. P1. Prot. Kyushu. 24:26-29. 3) Summers, E. M., Brandes, E. W. and Rands, R. D. (1948). U. S. Dept. Agr. Tech. Bull. 955: 44-90. 4) Abbott E. V. and Tippett, R. L. (1966). U. S. Dept. Agr. Tech. Bull. $1340: 1-25 . \quad 5)$ Ohtsu, Y. (1982). Ann. Phytopath. Soc. Japan $48: 390$ (Abstr.). 
(0.1 M, pH 7.0) (nine times the leaf weight) containing L-cystein monohydrochloride, monohydrate $(0.01 \mathrm{M})$, and the homogenate was kept on ice bath until use. The isolate was mechanically transmitted to healthy sour grass plants, causing mosaic symptoms (Plate I-1) similar to those on the originally diseased plants. The isolate was recovered from the sour grass plants infected after the inoculation.

In order to analyse the changes in the virus concentration in corn leaves at high temperatures $\left(26^{-38} \mathrm{C}\right)$, a series of ten fold diluted saps $\left(10^{-1}-10^{-5}\right)$ was prepared from the middle part $(5 \mathrm{~cm})$ of leaves of the inoculated corn plants at regular intervals after inoculation. Each sap was inoculated to a set of ten corn plants. The virus concentrations of these saps were estimated by Diener's assay on systemic hosts ${ }^{6}$. Results of the test are shown in Fig. 1. Chlorotic spots appeared two to three days after the inoculation on the upper leaves of the plants. High concentrations were observed four to twelve days after inoculation. Therefore, for further tests, leaves were used eight to ten days after inoculation in summer, while leaves were used about 14 days after inoculation in winter.

The isolate was mechanically inoculated to various species of plants. After 14-21 days' observations, recovery tests to the corn plants was carried out to determine whether the inoculated plants were infected with the isolate. Results of the inoculation tests are presented in Table 1 . The isolate was transmitted to 12 species of family Gramineae, but not to Job's Tear Coix lacryma-jobi, two species of genus Nicotiana, and C. amaranticolor. In the differential varieties of sugarcane used for the SCMV strains, the isolate produced mild mosaic symptoms on CP29-291 and CP31-294, mild mosaic, chlorotic stripes and flecks on CP31-588 (Plate I-2), these being the typical symptoms ${ }^{4)}$ caused by SCMV-A strain. The isolate could not systemically infect sugarcane cvs. NCo310 and F161, although it was able to infect their inoculated leaves.

The aphid transmission was tested on 30 corn plants by giving to a plant five aphids which had been starved for 2-2.5 hr. Acquisition feeding tested 3-5 min, and inoculation feeding $24 \mathrm{hr}$. The isolate was transmitted in a non-persistent manner to five corn plants out of the 30 ones tested with Aphis gossypii, and similarly to five corn plants out of 30 tested with Rhopalosiphum maidis.

The inactivation in sap was tested using the juice extracted with distilled water (nine times the leaf weight) from infected corn leaves 14-15 days after inoculation in winter time, and the saps which were treated in various ways were inoculated to a set of ten corn plants, respectively. By this test it was shown that the dilution end-point ranged between $10^{-4}-10^{-5}$, the thermal inactivation point between $55-60 \mathrm{C}(10 \mathrm{~min}$ ), and that the logevity in vitro was less than $24 \mathrm{hr}$ at 18-25 C. All five samples from infected leaves frozen at $-40 \mathrm{C}$ for 21 months were able to induce mosaic symptoms on all of the ten corn plants tested.

Purification of the isolate was performed according to a modification of the method described by Sako et al. (1980) ${ }^{7)}$ for watermelon mosaic virus in using 0.1 M potassium phosphate buffer pH 7.0 (PB) for extraction, 0.01 M PB for resuspension, and one cycle

6) Diener, T. O. (1979). In Viroid and Viroid Diseases, John Wiley \& Sons, New York. pp. 79-80.

7) Sako, N., Matsuo, K. and Nonaka, F. (1980). Ann. Phytopath. Soc. Japan 46:639-646. 
Table 1. Host range of the virus isolate and the symptoms on test plants

\begin{tabular}{|c|c|c|c|}
\hline \multirow{2}{*}{\multicolumn{2}{|c|}{ Test plants }} & \multicolumn{2}{|c|}{ Symptoms ${ }^{\text {a) }}$} \\
\hline & & Inoculated leaves & Upper leaves \\
\hline \multicolumn{4}{|l|}{ Gramineae } \\
\hline \multicolumn{2}{|l|}{ Paspalum conjugatum Berg. } & $\mathrm{L}$ & M \\
\hline \multicolumn{2}{|l|}{ Panicum maximum Jacq. } & $\mathrm{L}$ & M \\
\hline \multicolumn{2}{|l|}{ Digitaria ducumbens Stent. } & $\mathrm{L}$ & M \\
\hline \multicolumn{2}{|l|}{ D. violascens Link } & $\mathrm{L}$ & M \\
\hline \multicolumn{2}{|l|}{ Pennisetum alopecuroides Spreng } & $\mathrm{L}$ & M \\
\hline \multicolumn{2}{|l|}{ Setaria pumila Roem. et Schult. } & $\mathrm{L}$ & M \\
\hline \multirow[t]{6}{*}{ Saccharum officinarum $\mathrm{L}$. } & 'CP31-588’ & $\mathrm{L}$ & $\mathrm{mM}, \mathrm{CS}, \mathrm{Fl}$ \\
\hline & 'CP31-294’ & $\mathrm{L}$ & $\mathrm{mM}$ \\
\hline & 'CP29-291' & $\mathrm{L}$ & $\mathrm{mM}$ \\
\hline & ‘Q58’ & $\mathrm{L}$ & $\mathrm{M}$ \\
\hline & 'NCo310' & L, CS & $\mathrm{O}$ \\
\hline & 'F161' & L, CS & $\mathrm{O}$ \\
\hline \multirow{4}{*}{\multicolumn{2}{|c|}{ Sorghum bicolor (L.) Moench }} & $\mathrm{L}$ & $\mathrm{M}$ \\
\hline & & $\mathrm{L}$ & $\mathrm{M}$ \\
\hline & & $\mathrm{L}$ & $\mathrm{M}$ \\
\hline & & $\mathrm{L}$ & $\mathrm{M}$ \\
\hline \multicolumn{2}{|l|}{ Eragrostis ferruginea Beauv. } & $\mathrm{L}$ & $\mathrm{M}$ \\
\hline \multicolumn{2}{|l|}{ E. tef Trotter } & $\mathrm{L}$ & M \\
\hline \multicolumn{2}{|l|}{ Coix lacryma-jobi L. } & $\mathrm{O}$ & $\mathrm{O}$ \\
\hline \multicolumn{2}{|l|}{ Euchraena mexicana L. } & $\mathrm{L}$ & $\mathrm{M}$ \\
\hline \multicolumn{2}{|l|}{ Zea mays L. 'Nakadama' } & $\mathrm{L}$ & M \\
\hline \multicolumn{4}{|l|}{ Non Gramineae } \\
\hline \multirow{2}{*}{\multicolumn{2}{|c|}{$\begin{array}{c}\text { Nicotiana tabacum L. 'Bright Yellow No. 4' } \\
\text { 'Xanthi' }\end{array}$}} & $\mathrm{O}$ & $\mathrm{O}$ \\
\hline & & $\mathrm{O}$ & $\mathrm{O}$ \\
\hline \multicolumn{2}{|l|}{ N. glutinosa L. } & $\mathrm{O}$ & $\mathrm{O}$ \\
\hline \multicolumn{2}{|c|}{ Chenopodium amaranticolor Coste et Reyn } & $\mathrm{O}$ & $\mathrm{O}$ \\
\hline
\end{tabular}

a) CS:chlorotic stripes, $\mathrm{Fl}$ : flecks, L: latent, $\mathrm{M}:$ mosaic, $\mathrm{mM}:$ mild mosaic, $\mathrm{O}$ : no symptoms and no virus recovered to Zea mays L. 'Nakadama'.

of differential centrifugation before subjecting the isolate to sucrose density gradient (20-50\%) centrifugation using a rotor RPS40T (Hitachi Co.). The virus preparation was recovered from the lower band (25-33 mm from meniscus) out of two bands formed in the tube. The preparation exhibited the typical UV absorption spectrum of nucleoprotein with a minimum at $243 \mathrm{~nm}$, maximum at $259 \mathrm{~nm}$, and a shoulder of tryptophane at $290 \mathrm{~nm}$. The final yield from $100 \mathrm{~g}$ of leaf tissue was $0.53 \mathrm{mg}(0.36-0.67 \mathrm{mg})$, which was estimated according to the extinction coefficient of 2.7 for $1 \mathrm{mg} / \mathrm{ml}$ solution of maize dwarf mosaic virus- $B^{8}$.

Particles in the partially purified preparation (before sucrose density gradient cen-

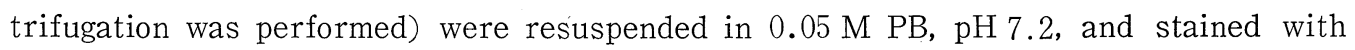
$2 \%$ uranyl acetate. The histogram of particle length distribution of the preparation showed that the majority of the particles were 750-780 nm long (Fig. 2 and Plate I-3).

8) Langenberg, W. G. (1973). Phytopathology $63: 149-154$. 


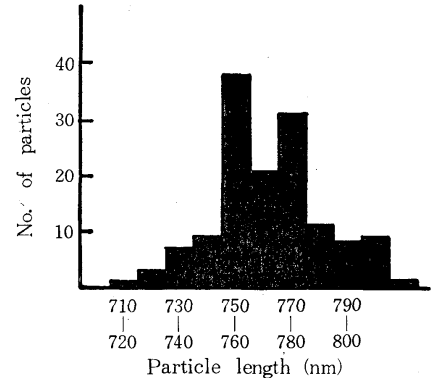

Fig. 2. Length distribution of the partially purified virus particles.

Antiserum was prepared by three intramuscular injections to rabbit with the purified virus sample containing Freund's complete adjuvant and by one intravenous injection. A quantity of $3.1 \mathrm{mg}$ of purified virus was divided for the four injections at one week intervals. To obtain the antiserum, blood sample was taken from the rabbit ten days after the last injection. The microprecititin test was carried out using a solution of $0.85 \% \mathrm{NaCl}$ in $0.01 \mathrm{M}$ imidazol buffer $\mathrm{pH} 7.6$ containing $0.02 \%$ sodium azide for dilutions of the serum and the partially purified virus, and using $0.1 \mathrm{M}$ imidazol buffer $\mathrm{pH} 7.6$ for the sap antigens ${ }^{9}$. The antiserum had a homologous titer of $1 / 512$ with partially purified virus. The healthy corn sap at a $2 / 5$ dilution reacted with the antiserum at a dilution of $1 / 16$. The partially purified virus also reacted at the titer of $1 / 256$ with SCMV-A antiserum which was provided by Dr. A. G. Gillaspie, Jr., USDA, having a homologous titer of $1 / 256$ in the microprecipitin test. The antiserum from USDA at a $1 / 4$ dilution did not react with the sap from healthy corn leaves.

Immunodiffusion tests were carried out in $0.85 \%$ agar plates containing $0.1 \%$ sodium dodecyl sulfate (SDS) and $0.3 \%$ sodium azide used for zucchini yellow mosaic virus ${ }^{10)}$. Samples were prepared by grinding two $\mathrm{g}$ of leaf tissue with two $\mathrm{ml}$ of distilled water and then filtering through four layers of gauze. To each one $\mathrm{ml}$ of the sap and $0.3 \mathrm{mg} /$ $\mathrm{ml}$ of the purified virus, $0.5 \mathrm{ml}$ of $2.1 \%$ SDS was added. The incubation period before introducing the solution to agar plates was $45-55 \mathrm{~min}$ at room temperature. The antigens were introduced in the outer wells 50-60 min after placing the antiserum into the central well.

The antiserum to the isolate produced a single precipitin band with the purified virus, two bands with the infected corn sap, and a single band with healthy sap. The inner band with the infected sap coalesced with the band with the purified virus, and the outer band coalesced with the band with healthy sap (Plate I-4). The antiserum also produced a strong precipitin band and a faint one with the saps from naturally diseased leaves of the sour grass, which were collected from 15 shoots of the plants respectively at three different locations in Ishigaki Island. The bands with the diseased sour grass saps coalesced with each other, and with the inner band containing the virus of infected corn sap. A weak band was produced with the sap of sour grass plants without symptoms (Plate I-5).

The results from our study on particle length $(750-780 \mathrm{~nm}$ ), host range (limited to family Gramineae) and symptomatology (mosaic on corn and sugarcane plants), transmission (by aphid in a non-persistent manner), and inactivation in sap were similar to

9) Noordam, D. (1973). In Identification of plant viruses, Methods \& experiments, Centre for Agric. Publ. and Docum., Wagenigen. p. 124. 10) Ohtsu, Y., Sako, N. and Somowiyarjo, S. (1985). Ann. Phytopath. Soc. Japan $51: 234-237$. 
those obtained with SCMV ${ }^{11)}$. The isolate reacted with the antiserum to SCMV-A from USA at $1 / 256$. The isolate induced mild mosaic symptoms on the differential sugarcane cvs. CP29-291 and CP31-294, and mild mosaic symptoms, chlorotic stripes and flecks on CP31-588 (Plate I-2). These symptoms on CP31-588 were found to be very similar to those of SCMV-A which appeared on CP31-588 in the test carried out by Dr. Gillaspie $^{15)}$. These results clearly indicate that the isolate corresponds to the strain $\mathrm{A}^{4)}$ of SCMV. Therefore, the isolate was designated as Is-1 of SCMV-A. We detected the SCMV-A from sour grass plants at three locations in Ishigaki Island by the immunodiffusion test.

Toriyama and Yora ${ }^{12)}$ reported four different isolates of SCMV obtained from wild grasses in Japan. However, since they did not use the American differential varieties of sugarcane, it is not possible to compare their isolates with the American strains of SCMV. We compared the symptoms caused by our isolate on ten gramineous species with the description of those caused by the isolates of Toriyama and Yora. Our isolate induced mosaic on Eragrostis ferruginea and E. tef at high rates, but did not infect Coix lacryma-jobi. This result and the reactions to the other species resemble those of one of the isolates, Kazekusa mosaic virus (KzMV), of the former authors. Therefore, it is suggested that our isolate is closely related to KzMV.

Nakata and Hidaka ${ }^{13)}$ reported the occurrence of sugarcane mosaic disease in Kagoshima prefecture. However, they did not identify the strain of the virus. Gillaspie and Mock $^{14)}$ reported strains B, H, and I of SCMV isolated from sugarcanes in Kagoshima. Gillaspie ${ }^{15)}$ also identified the strain $\mathrm{H}$ of SCMV obtained from sugarcane cv. NCo310 in Okinawa Main Island. Recently, one of the authors ${ }^{16)}$ reported the occurrence of strain $\mathrm{H}$ of SCMV in Ishigaki island, Okinawa. Therefore, this is the first report on the occurrence of the strain A of SCMV in Japan.

The isolate did not cause systemic infection in sugarcane cvs. NCo310 and F161 which are widely cultivated in Yaeyama Islands including Ishigaki island. Therefore, it is unlikely that SCMV-A may become the pathogen of sugarcane mosaic disease under the present conditions in Ishigaki Island. However, it will be necessary to check promising lines of sugarcane for their reaction to SCMV-A.

We are grateful to Dr. A. G. Gillaspie, Jr., U. S. Dept. Agr., for providing the antiserum of SCMV-A and for the diagnosis of the symptoms on CP31-588; to Dr. M. Sorin, Kogakukan Univ., for identifying the aphids tested; to Dr. Teakle, D. S., Univ. of Queensland, Dr. S. Toriyama, Tokyo Univ., Mr. H. Yoshida, Tropical Agric. Res. Center, and Dr. G.T. A. Benda, U. S. Dept. Agr., for providing seeds of test plants. We are also grateful to Dr. T. Gotoh, Okinawa Branch of Tropical Agric. Res. Center, and Dr. N. Sako, Saga Univ., for revising the manuscript; and to Dr. J. Bartman, Tropical Agric. Res. Center, for revising the English text.

11) Pirone, T. P. (1972). C. M. I./A. A. B. Descriptions of Plant Viruses. No. 88. 12) Toriyama, S. and Yora, K. (1972). Virus diseases of Wild Grasses and Cereal Crops in Japan, Univ. Tokyo Press. Tokyo. pp. 68. 13) Nakata, E. Hidaka, Z, (1975). Memoirs Assoc. P1. Prot. Kyushu. 3 : 1-32. 14) Gillaspie, A. G., Jr. and Mock, R. G. (1979). Sug. Path. Newsl. $22: 21-23$. 15) Gi1laspie, A. G., Jr., personal communication. 16) Ohtsu, Y. (1985). Ann. Phytopath. Soc. Japan 51 : 64 (Abstr.). 


\section{和 文 摘 要}

大津善弘・五味唯孝：オガサワラスズメノヒエから分離されたサトウキビモザイクウイルス A系統

石垣島でオガサワラスズメノヒエのモザイク病株から分離されたウイルスはイネ科13種のうち12種に全身感 染し, サトウキビの判別用 3 品種に軽微なモザイク, CP31-588 には SCMV-A 特有の退緑斑点を生じ, 26〜 38C下ではトゥモロコシ ‘中玉’ で接種 4 12日後に高濃度に達した。本ウイルスは R. maidis と A. gossypii により非永続伝搬された。部分純化したウイルスは長さ 750-780 nm の粒子が多く, ウイルスを家鬼 飞注射して得た抗血清は微滴法による力価が512倍で，寒天ゲル内 拡散法により罹病 ‘中玉”汁液と反応し， 寄主蛋白の沈降線と明膫に区別できるウイルスによる沈降線を生じた。本ウイルスは米国の SCMV-A 抗血清 之微滴法により256倍まで反応した。以上の結果，本ウイルスを SCMV-A と同定した。A系統のわが国での 発生記録はてれが初めてである。

(Received July 22, 1985)

\section{Explanation of plate}

\section{Plate I}

1. Mosaic on sour grass leaves infected with the isolate.

2. Chlorotic stripes and flecks on sugarcane leaf (cv. CP31-588) infected with the isolate.

3. Electron micrograph of partially purified virus of the isolate negatively stained with $2 \%$ uranyl acetate. Bar represents $300 \mathrm{~nm}$.

4. Immunodiffusion test of the isolate. Central well contains the antiserum to the isolate. Outer wells contain SDS-treated antigens from corn leaves; 1 , purified virus of the isolate; 2 , the isolate in sap; 3 , healthy corn (cv. Nakadama).

5. Immunodiffusion test of the isolate and naturally diseased saps of sour grass. Central well contains the antiserum to the isolate. Outer wells contain SDS-treated antigens from corn and sour grass leaves. 1-3, naturally diseased sour grass collected respectively at Maesato (1), at the different spot of Maesato (2), and at Kainan (3); 4 , the isolate in corn sap; 5 , healthy corn plant; 6 , sour grass plant without symptoms. These antigens were poured in the outer wells 2.5 hours after pouring the antiserum in the central well in this test. 
Plate I
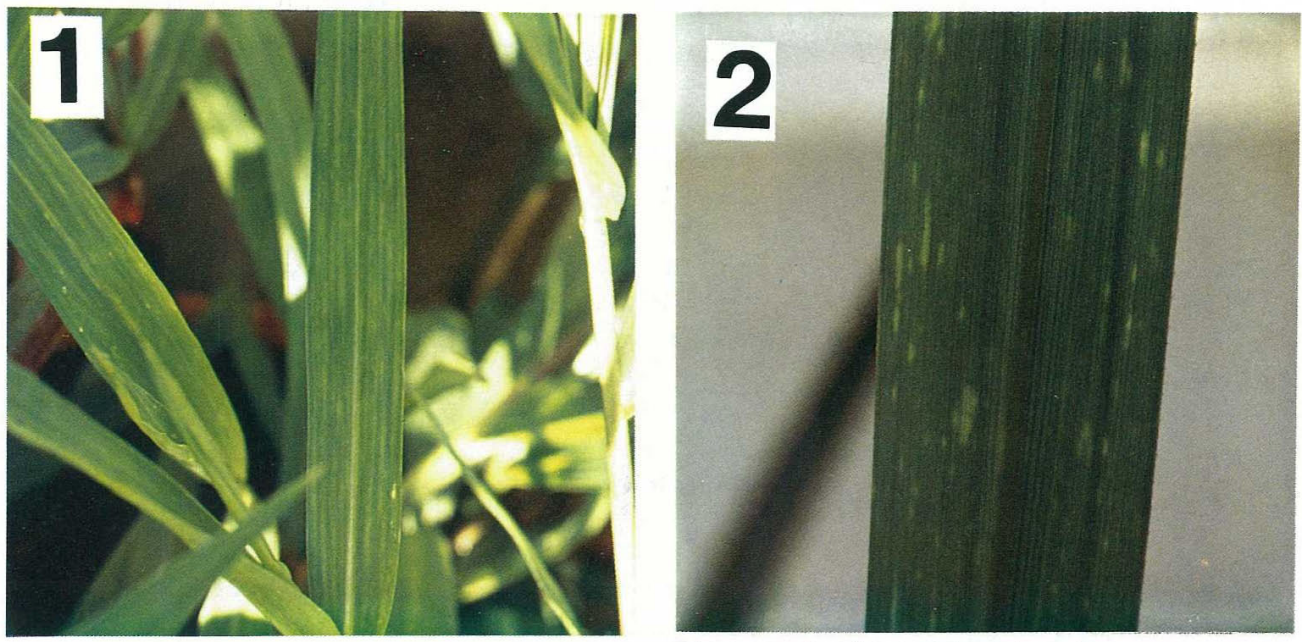

3
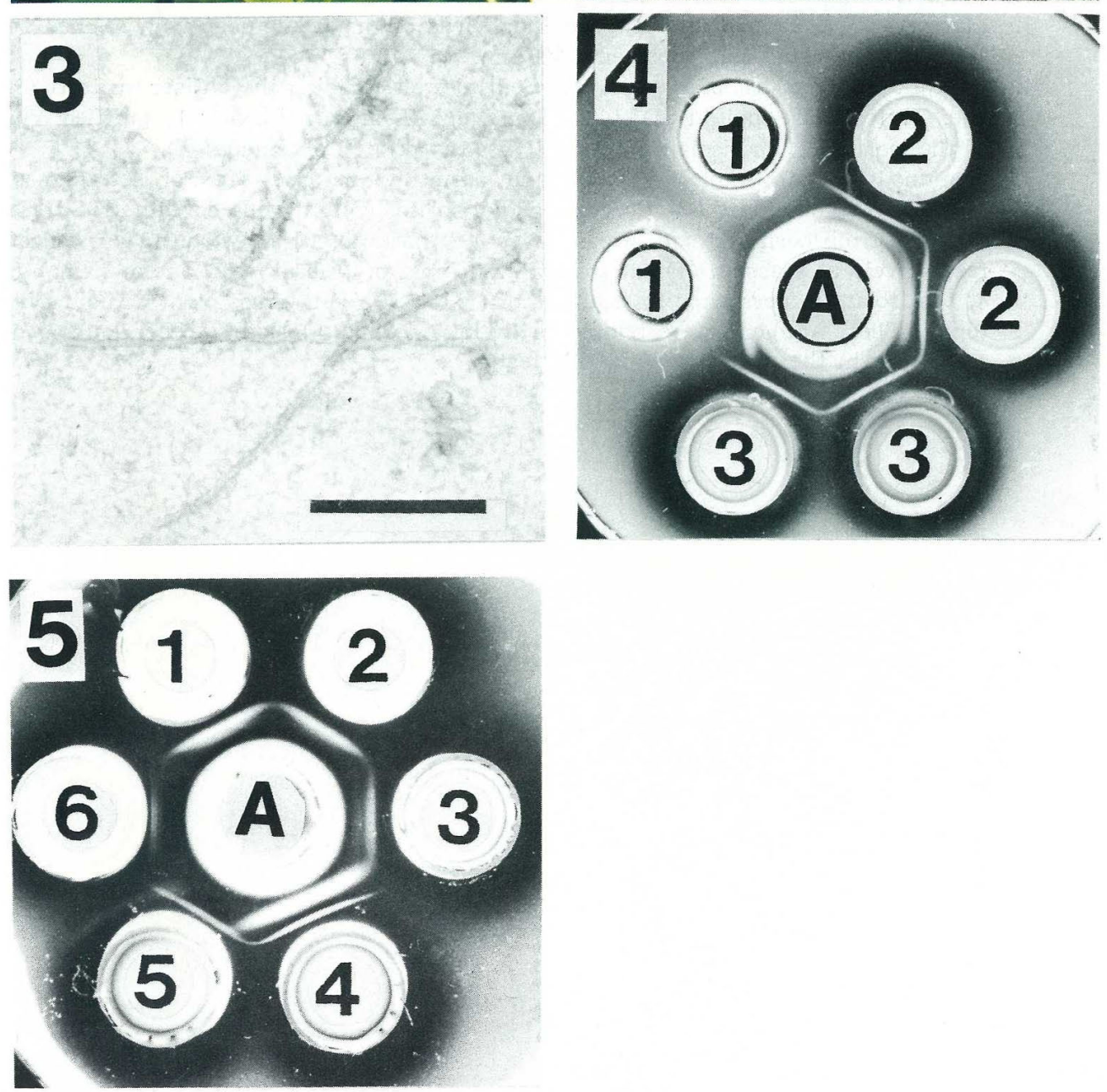